\title{
Legal Problems Regarding the Implementation of the Obligation to Read the Notary Deed
}

\author{
Hendy Hendariyadi*), Jawade Hafidz ${ }^{* *}$ and Soegianto***)
}

\author{
*) Student Master of Notary Law, Faculty of Law, Universitas Islam Sultan Agung \\ Semarang, E-mail: hendyhendariyadi08@gmail.com \\ **) Lecturer Master of Notary Law, Faculty of Law, Universitas Islam Sultan Agung \\ Semarang \\ ***) Lecturer Master of Notary Law, Faculty of Law, Universitas Islam Sultan Agung \\ Semarang
}

\begin{abstract}
Reading the deed is an obligation in every authentic deed is made, the reading of the deed by a notary is part of the verlijden or the inauguration of the reading and signing of the deed in question. If the reading of this deed is related to the making of an authentic deed which is part of perfect proof, it is clear that making a notary deed requires the real presence and physical position of the parties concerned. The purpose of this research is to analyze the Notary Public is obliged to read out the deed made based on Act No. 2 of 2014 concerning the Position of Notary Public, To analyze the legal problems of reading deeds made by the Notary, To analyze the legal consequences of deeds that are not read by a Notary based on Act No. 2 of 2014 concerning the Position of a Notary Public. The method used in this research is the method used in this research is juridical empirical, namely an approach based on applicable law and based on reality in practice. The juridical approach is used to analyze regulations that are related to the Notary Law, while the empirical approach is used to analyze the obligations of notaries in reading deeds which are seen as community behavior that has a pattern in community life that always interacts and relates to social aspects. namely an approach based on applicable law and based on reality in practice. The juridical approach is used to analyze regulations that are related to the Notary Law, while the empirical approach is used to analyze the obligations of notaries in reading deeds which are seen as community behavior that has a pattern in community life that always interacts and relates to social aspects. namely an approach based on applicable law and based on reality in practice. The juridical approach is used to analyze regulations that are related to the Notary Law, while the empirical approach is used to analyze the obligations of notaries in reading deeds which are seen as community behavior that has a pattern in community life that always interacts and relates to social aspects. The legal problem of reading deeds made by notaries, related to article 16 paragraph 7 of the Law on Notary Position regulates deviations from article 16 letter $m$. Where in Article 16 paragraph 7, it is stated that the reading of the deed is not mandatory, if the viewer wants the deed not to be read because the viewer has read it himself, knows and understands its contents, provided that it is stated in the cover of the deed and also on every minuta deed page initialed by the parties, and witnesses, as well as a notary. The legal consequence of the deed which is not read out by the notary based on Act No. 2 of 2014 concerning the Position of
\end{abstract}


Notary Public, the deed which is not read out is still an authentic deed as long as the reasons for not reading the deed are stated.

Keywords: Legal Problems; Obligations; Notary Deed.

\section{INTRODUCTION}

Notary Public is an official general which in Dutch is called Openbare Ambtenaren. Notary Public as an official The general public has a central role in law enforcement in Indonesia, because in addition to the sufficient quantity of notaries high, notaries are also included in the elite structure in Indonesia, meaning between society on generally notary in terms of sociological, political, and economic the stratification is higher.

The birth of Constitution Number 22014 concerning amendments to Act No. 30 of 2004 concerning positions Notary (UUJN), to emphasize or strengthen the position of the notary as an official general which provides certainty law through an authentic deed he made. Base philosophical creation Position Law Such a notary has been amended by Act No. 2 Year 2014 regarding amendments to Act No. 30 of 2004 concerning Notary position, namely the realization of a guarantee certainty law, order and truth-based legal protection, and justice. Using the deed he made, notary must be able to provide certainty law to service user community Notary Public. ${ }^{1}$

Based on article 1 Constitution number 22014 concerning the position of notary stated that a notary is a public official who has the authority to make authentic and own actuaries other authorities as referred to in this Law or under the law other. In the article above mentions duties notary is deed maker, and duty This notary is to guarantee certainty law for parties who make the agreement so that the parties have strong evidence in case of dispute.

Notaries have the duty to provide information to the public regarding the making of deeds authentic, that way, the notary must be able to fully understand all the provisions regulated by law so that the general public, who do not really understand the rules of law, are able to understand correctly and also not commit acts that are against the law.

Duty Notaries provide assistance regarding making authentic deeds. In this way, it is important for the Notary to know or understand the provisions regulated by law so that the general public who does not understand or do not understand legal rules can understand correctly and also do not do things that are contrary to the law. ${ }^{2}$ The position of a notary is based on the notary public and the party who uses his services.

Attendance notaries are wanted by legal rules that aim to serve and assist people who need authentic written evidence about events, circumstances, or legal acts.

${ }^{1}$ Ira Koes. (2013). Ke Notaris. Depok: Raih Asa Sukses. p. 9

${ }^{2}$ Komar Andasasmita. (1993). Notaris Selayang Pandang, Cet. 2, Bandung: Alumni. p.2 
Based on this, those who serve as notaries must have enthusiasm in serving the community. ${ }^{3}$

Reading the deed is an obligation in every authentic deed is made, the reading of the deed by a notary is part of the verlijden or inauguration from the reading and signing of the deed concerned. If the reading of this deed is related to the making of an authentic deed which is part of perfect proof, it is clear that making a notary deed requires the real presence and physical position of the parties concerned.

Based on the description above, the writer intends to compile a writing on the title "Legal Problems Regarding the Implementation of the Obligation to Read the Notary Deed".

Based on the description of the background that has been presented, the authors formulate the following problems:

1. How is the practice of the notary in carrying out its obligation to read the deeds made?

2. How are the legal problems regarding the reading of deeds made by notaries?

3. What is the legal consequence of the deed not being read out by the notary?

\section{RESEARCH METHODS}

Researchers used a legal research method with an empirical juridical approach, the research specification used was descriptive analytical, the data source came from secondary data. Data collection methods are carried out through interviews, library research, and document study. This writing is analyzed by qualitative analysis using the analysis knife of legal certainty theory, theory of responsibility, and theory of authority.

\section{RESULTS AND DISCUSSION}

\subsection{Notary Practices In Carrying Out Their Obligations To Read The Deed That Was Made}

The authentic nature of a deed is a component or element that fulfills the will to realize a legal certainty. An authentic deed includes a statement regarding the rights and obligations of a person or individual (in the civil field) and therefore protects a person from these interests. A deed consists of Head of Deed, Comparition, Deed Premisse, Body / Content of deed, and End of Deed.

In his role, a notary is not on the side of his client, the notary's position is "outside the parties", the notary is not a party to the deed or a party to the deed. The special characteristics that characterize a notary, namely being impartial and having an independent position, provide a strong basis for public

\footnotetext{
${ }^{3}$ R.A. Emma Nurita. (2012). CYBER NOTARY (Pemahaman Awal Dalam Konsep Pemikiran). Cet. 1 Bandung: Refika Aditama. p. 15.
} 
accountability for mistakes made by a notary in carrying out his / her job duties.

Based on article 16 paragraph (1) letter d UUJN, notaries without valid arguments or reasons, may not refuse to provide assistance, so that the free will of the notary as appropriate to reach an agreement on an agreement is not fulfilled. Deeds made before a notary are classified into two types of deeds, namely party deeds and official deeds. In the party deed, the notary is released from responsibility if it turns out that later what the parties explain is not true. The notary guarantees that the tappers correctly stated what was stated in the deed but the notary did not guarantee that what was said by the tappers was true or a truth.

Deed containing minutes of an event heard and seen by the notary itself. In this position, the notary is fully responsible for the accuracy of the contents of the deed he has made. For example the Minutes of the General Meeting of Shareholders of a Company. Notaries can not be held responsible for losses that arise as a result of the deed drawing and also the preparation and implementation as long as the assistance provided by the notary has been carried out in accordance with the applicable provisions in UUJN, other laws and regulations within reasonable accuracy.

The reading of the deed is not only beneficial for the notary but also beneficial for tappers, as for the benefits of reading the deed by the notary, namely as follows:

1) Notaries still have the opportunity to correct previously unseen mistakes. With the reading of the deed, there is a last possibility for a notary to check the deed he has made, but this benefit is not the only one.

2) The parties will get the opportunity to ask about things that are not clear to him in the deed.

The reading of the deed is an opportunity for the notary and the tappers at the last second, before the deed is formalized with the signing of the parties, witnesses, and also the notary to rethink, in other words, revise the contents of the agreement so that unwanted problems do not occur at a later date.

Based on the theory of authority, the notary has attribution authority, meaning that the notary is given direct authority by the law to make deeds including reading the authentic deed he makes and when the object of an agreement is still in the notary's working area, so the notary always has the authority to make the deed even though reading of the deed of signing the deed is done by video conference.

In the development of notarial deeds so far referring to Act No. 2 of 2014 concerning Amendments to Act No. 30 of 2004 concerning the Position of Notary Public, it is clear that changes to the deeds making guidelines have been made so that from the formulation guidelines the Law on the Position of Notary is further explained. not only in the form of a notary deed, but all matters that have to do with the duties and powers and responsibilities of the notary, as the official who has the authority to make an authentic deed in the form of a notary deed. 


\subsection{Legal Problems From Reading Deeds Made By Notaries}

Authority is a legal action that is regulated and permitted in a position based on the prevailing laws and regulations concerning the position concerned. In administrative law, authority can be obtained by attribute, delegation, or mandate. Attribute authority is the granting of new authority to a position based on statutory regulations or legal regulations. Although mandated authority is not a transfer or transfer of authority, it is because those concerned are unable to do so.

Based on the Law on Notary Position (UUJN), it turns out that notaries as public officials, get authority by attribution, this is because the authority is issued and granted by UUJN itself. With that said, what the notary gets is not from other institutions, for example the Department of Law and Human Rights. Notary is a profession that can be traced back to the third century, in ancient Rome, where they were known as a scribae, tabellius, or notarius. At that time, they were the class of people who recorded speeches. The term notary is taken from the name of the servant, notarius, which then becomes a term or title for a group of fast writers or stenographers. ${ }^{4}$

Based on the definition of deed above, what is meant by authentic deed must meet or complete the following criteria:

1) The form is in accordance with the provisions of the Law; The form of notarial deed; Marriage certificate; The format and contents of the birth certificates have all been determined by law. However, there are also deeds which are agreements between the two parties whose contents are based on an agreement between the two parties in accordance with the principle of freedom of contract;

2) Made in the presence of authorized public officials;

3) Its proving power is perfect;

4) If it is argued about its truth, then the denier must verify its untruth. Unlike the authentic deed, the deed under the hand has its own characteristics and characteristics in the form of:

a. The form tends to be free;

b. It does not have to be made in front of a public official;

c. It still has the power of proof as long as it is not denied by the maker;

In the event that it must be proven, it must also be fulfilled by witnesses and other evidence. Therefore, usually in an underhand deed, 2 (two) adult witnesses should be included in order to strengthen the evidence.

In article 16 number 1 letter $\mathrm{m}$ of the Law on the Position of Notary Public number 2 of 2014, notaries are required to read the deed before the witnesses and witnesses, so in the guidelines for the formulation of a notary deed, the notary deed must be read out, but there are exceptions in the matter of reading. this deed, if the parties want and state that the deed does not need to be read and understood by the parties, the notary does not need to read the notary deed again.

${ }^{4}$ G.H.S. Lumban Tobing. (1992). "Peraturan Jabatan Notaris", Jakarta: Erlangga 
In practice, even though there were witness threats to violations of article 16 paragraph 1 letter $\mathrm{m}$ of the Law on Notary Position Number 2 of 2014, some notaries continued to deviate from the provisions of reading the deed, the reading of the deed was carried out by notary employees and even worse it was agreed by the parties and witnesses in the field usually use this excuse to save time.

Elucidation of article 16 paragraph 1 letter m Law of Notary Position Number 2 of 2014, this article reads: "that notaries are required to be physically present and sign a deed before the parties and witnesses"

In article 16 point 7 of the Law on the Position of a notary, it regulates deviations from article 16 letter $\mathrm{m}$. Article 16 point 7 states that the reading of the deed is not mandatory, if the viewer has read it himself, knows, and understands its contents, provided that it is stated in the closing of the deed and on every page of the deed is signed by the actor, witness and notary public. The existence of this provision allows and provides space for the notary to have the opportunity to make irregularities in the reading of the deed. Where in practice it is possible that the parties read in full from the deed itself without any translation from the notary if the parties do not ask questions. Meanwhile, in the Law on Notary Position Number 2 of 2014 in article 16 paragraph 8 that the provisions of Article 16 paragraph 7 are exempted from the reading of the head of the deed, comparisons, a brief and clear explanation of the principal of the deed, as well as the closing of the deed. With the provisions regarding the reading of the deed contained in the amendment to the Law on the Position of Notary Public, it is an obligation that is still carried out by the notary.

In connection with the theory of legal certainty put forward by Utrecht, namely, the first is that there are general rules that make individuals understand what actions can and cannot be done, meaning that notaries generally have to read the deed so that the audience understands, and the applicants must listen completely and clearly, in order to avoid a legal problem in the future. The second is legal security for individuals from government abuse, meaning that with legal certainty, namely reading the deed, the actors will be avoided from government arbitrariness, in this case represented by a notary.

In connection with the theory of responsibility put forward by Hans Kelsen, namely a person is legally responsible for a certain act or that he bears legal responsibility, the subject means that he is responsible for a sanction in case of conflicting actions, meaning that the notary as the duty bearer represents The state must be accountable for its actions, in this case the making of deeds, so based on this theory the notary is legally obliged to read the deed, so as to avoid sanctions if it is not read out.

\subsection{Legal Consequences Of Deeds Not Read By Notary Public}

Law is an element or component that is so important in social life. Law has a function to regulate everything in social life so that an orderly life can be realized. Apart from this, the law also has a function to maintain order and create a peaceful atmosphere. In practice the law itself has an important purpose, namely benefit, and certainty, as well as justice. The law must provide justice for all parties so as to give birth to an appropriate life, the law must also provide benefits to anyone, in order to create a process of legal awareness for the wider community. 
Law must be able to guarantee certainty for all members of society, because law must regulate firmly and logically, firmly meaning that it does not cause doubts (multiple interpretations) and logically means that law becomes a norm system against other norms, so that there is no conflict or cause conflict of norms. Legal certainty refers to the enforcement of law that is permanent, firm, and consistent and consequent, the implementation of which cannot be influenced by events that are subjective in nature.

Notaries in carrying out their duties, are also closely related to these legal objectives. Notaries are public officials who have the authority to make authentic deeds and other powers as explained in this Law as stated in article 1 paragraph (1) of Act No. 2 of 2014 concerning the Position of a Notary. based on this article, it is quite clear and unequivocal that the task of a notary is to make an authentic deed, where the authentic deed is one of the legal products. In preparing an authetic deed, a notary must not forget the three legal objectives above. The position of a notary as a functionary in society is considered as an official where someone gets reliable advice and produces strong documents in a legal process. Society needs a figure (figure) whose provisions are reliable, trustworthy, whose signature and everything (position stamp) provide strong guarantees and evidence, an expert who does not take sides with either party and an advisor who has no defects, who keeps his mouth shut, and makes a an agreement that could protect him in the future.

One of the procedures in making a deed is reading the deed. The reading of this deed can also be referred to as a procedure to formalize a deed (verlijden). The reading process until the signing of the deed must be carried out by a notary public and cannot be represented. This is an obligation for a notary which will affect the authenticity of the deed. This is contained in article 16 letter $\mathrm{m}$, namely reading the deed before the face of the audience in the presence of at least 2 (two) witnesses, or 4 (four) special witnesses for the making of a will under hand, and signed at that time by the witness, and notary. ${ }^{5}$

In article 16 paragraph 7 of the Law on the Position of Notary Public regulates deviations from Article 16 letter $\mathrm{m}$ which states that the reading of the deed is not mandatory, if the parties want the deed not to be read because the offender has read it himself, knows, understands its contents, provided that this is stated in the closing of the deed and also on each page of the minimum deed signed by the witnesses, witnesses and notaries. This provision allows and provides space for the notary to make irregularities in the reading of the deed. In practice it is possible that the parties read the entire deed by themselves without any explanation from the notary if the parties do not raise questions.

In carrying out the duties of a notary that applies the basis for deviation reading of article 16 paragraph 7 of Act No. 2 of 2014 concerning the Position of Notary Public, namely where the parties read themselves and do not carry out the provisions of Article 16 paragraph 8 to read the beginning and end of the act. If this is done, then what about the authenticity of the deed he makes. The law itself regulates that the process of making an authentic deed that does not meet the applicable requirements, conditions and procedures will change the power of the deed to an underhand deed. Decrease in deeds or what is called degradation

${ }^{5}$ Edwar, Faisal, Dahlan ali. Februari 2019," Kedudukan Notaris sebagai Pejabat Umum Ditinjau dari Konsep Equality BeforeThe LaW' Jurnal Hukum \& Pembangunan 49 No.1. Undang-Undang Nomor 2 Tahun 2014 Tentang Jabatan Notaris Ps 16 ayat (1) 
of deeds can happen without an instant, and there must be proof. For example: waarmerking, meaning that the letter or document concerned is registered in a special book made by a notary.

\section{CLOSING}

The notary is obliged to read out the deed he has drawn up based on Act No. 2 of 2014 concerning the Position of Notary Public, in order to make a guarantee for the parties that the signed deed is the same as what has been read, and the deed reading is carried out so that the tappers get a certainty that the writing or content of the deed is really the will of the parties. The reading of the deed is not only beneficial for the notary, but also for the tappers. The legal problem of reading deeds made by notaries, related to article 16 paragraph 7 of the Law on Notary Position regulates deviations from article 16 letter m. Where in Article 16 paragraph 7 it is stated that the reading of the deed is not mandatory, if the applicant wants the deed not to be read because the applicant has read it himself, knows, and understands its contents, provided that it is stated in the cover of the deed and also on each page of the deed signed by the actor, witness, and notary public. This provision allows and gives the notary the opportunity to commit irregularities in the reading of the deed where in practice it is possible that the parties read the entirety of the deed themselves without any explanation from the notary if the parties or the parties do not ask questions. The legal consequence of the deed that is not read out by the notary based on Act No. 2 of 2014 concerning the Position of Notary Public, the deed which is not read out is still an authentic deed as long as the reason for not reading the deed is stated, but if the notary deliberately does not read it and does not include it could be the deed that was previously authentic can the power of proof be a deed under hand.

Notaries in carrying out their duties and positions must be more vigilant or increase prudence in the service process towards the wishes of those who want an authentic deed to be made before a notary in accordance with Act No. 2 of 2014 concerning the Position of Notary Public, and also in accordance with regulations. others that have something to do with the position of notary public. Notaries must be more vigilant and careful in carrying out their duties and positions and constantly control and check every deed they make so as not to cause errors. In order to maintain the trust given by the law to the Notary Institution and to provide protection or to secure those requesting services to the notary, it is stated that the notary reads and provides an explanation of the deed he has made, because there are still many people who are laymen or do not really understand the laws contained in the deed. The notary must be more thorough in the implementation of the deed-making procedure if the parties want the notary to read the deed, then it must be ensured that the parties read the deed before him and ensure that the parties have signed a signature on each sheet of the deed drawn up by the notary. 


\section{REFERENCES}

Journals:

Edwar, Faisal, Dahlan ali. Februari 2019," Kedudukan Notaris sebagai Pejabat Umum Ditinjau dari Konsep Equality BeforeThe LaW' Jurnal Hukum \& Pembangunan 49 No.1. Undang-Undang Nomor 2 Tahun 2014 Tentang Jabatan Notaris Ps 16 ayat (1)

Books:

Ira Koes. (2013). Ke Notaris. Depok: Raih Asa Sukses

Komar Andasasmita. (1993). Notaris Selayang Pandang, Cet. 2, Bandung: Alumni

R.A. Emma Nurita. (2012). CYBER NOTARY (Pemahaman Awal Dalam Konsep Pemikiran). Cet. 1 Bandung: Refika Aditama

G.H.S. Lumban Tobing. (1992). "Peraturan Jabatan Notaris", Jakarta: Erlangga 